\title{
Güliver’in Gezileri adlı eserin değerler eğitimi açısından incelenmesi
}

\section{Hulusi GECGGEL ${ }^{1}$}

\section{Ebru DURAK²}

\begin{abstract}
APA: Geçgel, H.; Durak, E. (2020). Güliver'in Gezileri adlı eserin değerler eğitimi açısından incelenmesi. RumeliDE Dil ve Edebiyat Arasstırmaları Dergisi, (19), 204-219. DOI: 10.29000/rumelide.752277.
\end{abstract}

\section{$\ddot{\mathbf{O} z}$}

Bu araştırmada Güliver'in Gezileri adlı eserin Türkçe Dersi Öğretim Programı’nda yer alan on kök değer açısından incelenmesi amaçlanmıştır. Araştırmada nitel araştırma yöntemlerinden dokuman inceleme yöntemi kullanılmıştır. Araştırmada elde edilen veriler betimsel analiz yoluyla analiz edilmiştir. Araştırmada çalışılan eser Jonathan Swift’in dört bölüm olarak yazdığı Güliverin Gezileri adlı eseridir. Eserde, adaletin önemine değinilmiştir. İftiranın yanlışlı̆̆ı ve hükümetin ceza sistemine bağlı olarak haklının ve adaletin yanında olması gerektiği belirtilmektedir. Eserde dostluğun önemi ve fedakârlık anlatılmaktadır. Kişideki iyi özelliklerin insanları birbirine yaklaştırdığı ve bununla birlikte dostluk kurabileceği ifade edilmiştir. Hile, hırsızlık gibi doğru olmayan davranışları ayırarak dürüstlüğe ve iyiliğe yöneltme amacı taşımaktadır. Gerektiğinde dürüst davranış gösterme ve tercihini dürüstlükten yana kullanabilme yetisinin önemi yansıtılmıştır. Kişinin öz denetime sahip olarak edindiği maddi ve manevi kazanımlar anlatılmaktadır. Kendi kendini denetleme ve buna bağlı olarak karar vermenin önemi üzerinde durulmuştur. Sabırlı davranışların sonuçları ile ilgili fikirler edinme üzerinde durulmuştur. Bilgiye ve akla duyulan saygı ifade edilmiştir. Eserde cimrilik ve önyargıyla ilgili bölümler de yer almaktadır. Bilgiye ve liderliğe duyulan saygı gösterilmektedir. Aile özlemi ve aileden ayrı kalmanın hüznü anlatılmıştır. Hayvanları korumanın ve onları sevmenin öneminden bahsedilmiştir. Ebeveynlerin sorumlulukları anlatılmaktadır. Ayrıca eğitime verilen öneme ve yaşam koşullarına da yer verilmiştir. Mensup olduğu ülkeye ve millete karşı sorumluluklarının farkına varma iletisi vardır. Dilin, hürriyetin ve vatanın önemi vurgulanmaktadır. Ülkede barış içinde yaşamanın ve kanunun öneminden bahsedilmektedir. Yardıma ihtiyaç duyulan durumları ayırarak doğru zamanda yapılan yardımın gerekliliğinden bahsedilmektedir. Sonuç olarak eserde Türkçe Dersi Öğretim Programı'nda belirtilen on kök değer etkili bir şekilde işlenmektedir.

Anahtar kelimeler: Değerler, on kök değer, değerler eğitimi, Güliver’in Gezileri

\section{Investigation of the works of Gulliver Travels of values education}

\begin{abstract}
In this study, it was aimed to examine the work named Güliver's Travels in terms of ten root values in the Turkish Lesson Teaching Program. In the research, document analysis method, one of the qualitative research methods, was used. The data obtained in the study were analyzed through descriptive analysis. The work studied in the research is Güliverin Geziler, written by Jonathan

1 Dr. Öğr. Üyesi, Çanakkale Onsekiz Mart Üniversitesi, Eğitim Fakültesi, Türkçe ve Sosyal Bilimler Bölümü, Türkçe Eğitimi ABD (Çanakkale, Türkiye), hgecgel@comu.edu.tr, ORCID ID: oooo-0oo2-9277-6417 [Makale kayıt tarihi: 06.05.2020-kabul tarihi: 20.06.2020; DOI: 10.29000/rumelide.752277]

2 YL Öğrencisi, Çanakkale Onsekiz Mart Üniversitesi, Eğitim Bilimleri Enstitüsü, Türkçe ve Sosyal Bilimler ABD (Çanakkale, Türkiye), drkebru@gmail.com, ORCID ID: 000o-0003-1086-5879
\end{abstract}




\begin{abstract}
Swift in four parts. In the work, the importance of justice is mentioned. It is stated that the slander should be on the side of the justice and justice due to the defamation and the government's penal system. The work tells about the importance of friendship and sacrifice. It has been stated that good traits in the person bring people closer together and can make friendship with it. It is aimed at honesty and goodness by separating the inaccurate behaviors such as cheating and theft. The importance of the ability to behave honestly when necessary and to use their preference for honesty has been reflected. The material and moral achievements that the person gained through selfcontrol are described. The importance of self-regulation and accordingly decision making is emphasized. It is focused on obtaining ideas about the results of patient behavior. Respect for knowledge and reason is expressed. It is included in the sections on stinginess and bias. Respect for knowledge and leadership is shown. The longing for family and the sadness of being separated from the family are explained. The importance of protecting and loving animals is mentioned. Parents' responsibilities are described. In addition, the importance given to education and living conditions are included. There is a message to realize their responsibilities towards the country and nation they belong to. The importance of language, freedom and homeland is emphasized. The importance of living peacefully in the country and the law is mentioned. It is talked about the need for help at the right time by separating the situations that need help. As a result, ten root values specified in the Turkish Lesson Curriculum are effectively processed in the work.
\end{abstract}

Keywords: Values, ten root values, teaching values, Gulliver Travels

\title{
Giriş
}

Değer sözcüğü, Türkçe Sözlük’te "Bir ulusun sahip olduğu sosyal, kültürel, ekonomik ve bilimsel değerlerini kapsayan maddi ve manevi ögelerin bütünü" ve "Bir şeyin önemini belirlemeye yarayan soyut ölçü, bir şeyin değdiği karşıllk, klymet, yüksek ve yararlı bir nitelik” (https://sozluk.gov.tr) olarak tanımlanmıştır. Psikoloji Sözlüğü’nde, "Belli bir toplumda, neyin iyi neyin kötü, doğru veya yanlış, arzu edilir veya arzu edilmez olduğu konusundaki ortak görüşler, standartlar” (Budak, 2000: 186); Sosyoloji Sözlüğü’nde, neyin doğru neyin yanlış olduğuyla ilgili fikirler olduğunu ifade etmektedir (Marshall, 1999: 133).

Değer bir şeyin arzu edilebilir veya edilemez olduğu hakkındaki inançtır. Ahlak felsefesinin en çözülemez problemlerinden biri olarak görülmektedir. Ahlaki değerin objektif bir temel olsaydı anlaşmazlıklardan kurtulabilinirdi (Güngör, 1998: 27). Değerler üzerine sistemli çalışmalar yapan Rokeach ise tutum ve değeri ayrı kavramlar olarak ele almaktadır. Aralarındaki en temel farkın değer tek bir inançtan oluşurken, tutum ise farklı inançlardan oluşmaktadır (Güngör, 1998: 29). Değerler, insan davranışlarını açıklamada önemli bir kaynaktır (Kuşdil ve Kağıtçıbaşı, 2000). Değer kavramanı tek bir tanım yoluyla açıklanamaz. Bu yüzden değer hakkında öznel ve nesnel olarak farklı tanımlar yapılabilir. Değer, kültür oluşturma, kültür içerisinde yaşamadır. Değerler bir anlamda kültürün taşıyıcılarıdır (Özlem, 2004: 178). Hayatın akışında bazı ayıklamalar yapıp, en somut şekilde bu değerlerin değerlenmesini bize göstererek, bu değerlerin değerlendirmesini yapmakta, bu değerlerle ilgili yaşantı imkânlarına işaret etmektedir Kuçuradi (1971).

Değerler toplumdan topluma değişebilmektedir. Değişen toplum yapılarına rağmen ortak özellikte pek çok değer bulunmaktadır (Tarhan, 2011). Bunlar bireysel gibi görünse de, toplumun hayat tarzını anlamlı kılan yaşamın kontrol mekanizması olarak görülmektedir Değerlerin toplum içerisinde doğru aktarımı, iyi ve ahlaklı bireyleri meydana getirecek, bu bireyler de toplumda huzur ortamının 
oluşmasını sağlayacaktır (Hökelekli, 2013). Kişilerin davranışları arasındaki dengeyi de kurabilen değerler, insan davranışlarını yönlendirmede önemli bir rol üstlenmekte, davranışlar konusunda etkili tutumlar geliştirebilmektedir (Acun, Yücel, Önder ve Tarman, 2013).

Çocukluk, değerlerin kazanılmasında önemli bir dönemdir. Çocuğun içerisinde bulunduğu aile, değerlerin kazanılmasında önemli bir rol oynar. Aileden sonra çocuğun etkilendiği en büyük etken çevredir. Teknolojinin gelişmesiyle beraber çocuğun vakit geçirdiği telefon, tablet ve televizyon çocuğun değer yapısının şekillenmesinde önemli bir rol oynamaktadır (Karaca, 2019). Okullarda değerler eğitimi konusunda öğretmenlere büyük bir rol düşmektedir. İlkokul ve ortaokulda yapılandırmacı eğitim anlayışına uygun olarak öğrencilerin aktif olduğu, öğretmenin rehber olduğu, öğrencilerin yaparak yaşayarak öğrenecekleri bir okul ortamına ihtiyaç duyulmaktadır (Çengelci, Hancı ve Karaduman, 2013). Ortaokul öğretmenleri, değerler eğitimi yoluyla öğrencilerin kendilerini ifade etme şansı bulduklarını, çevresindeki değerlerden yola çıkarak kendi değerlerini sorguladıklarını ifade etmektedir. Değerler eğitimi çocuğun sadece bilişsel yönüne değil, duyuşsal ve psikomotor becerilerine de katkı sağlamaktadır (Koç, 2016).

Öğretim programı öncelikle beceri kazandırmak üzerine oluşturulurken, yeni hazırlanan öğretim programları milli ve manevi değerleri kazandırmayı ön plana almıştır. Değerler özellikle 2005’ten sonra hazırlanan programlarda her derste üzerinden durulması gereken bir başlık olarak ele alınmıştır. 2019 yılında hazırlanan öğretim programlarıyla öğrencilere kazandırılması hedeflenen değerler on ana başlık altında toplanmış ve bunlar "on kök değer" olarak ifade edilmiştir (Diker Coşkun, 2017: 16). Değerler eğitiminin amacı öğrencilerde öncelikle sağlıklı bir kişilik oluşturmayı hedeflemiştir. Değerler, dünyayı daha iyi bir hale getirmek için bireyin kazanması gereken becerilerdir. Öğretim programlarında yer alan on kök değer ve bu değerlere ilişkin örneklendirilen tutum ve davranışlar değerlere ilişkin evrensel tanımlamalarla belirli bir ölçüde örtüşmektedir (Sunar, 2018:49).

Türkçe Dersi Öğretim Programı’nda (MEB, 2019: 4) değer kavramının öğretim programlarının perspektifini oluşturduğu belirtilmiştir. Değerler, bir milletin kökleri, gelenek ve görenekleridir. Bugünümüzü besleyen bu kökler yarınımıza ışı olmaktadır. MEB Talim ve Terbiye Kurulu Başkanlığı'nın yaptığı basın açıklamasında mevcut müfredatların çağın gereklilikleri ve gelişmeleri doğrultusunda yenilendiği açıklanmıştır. Bu açıklamada müfredatın ana odağını oluşturan değerler güncelliğini korumuştur. Öğretim programları, değerler eğitiminin uygulanması ve geliştirilmesinde önemli bir rol oynar. Okulda öğretmen ve öğrenciler tarafından yapılan etkinlikler, öğrencilerin değerlerle ilgili davranışlarını beceriye dönüştürmelerini sağlar. Yenilenen öğretim programlarında değerler eğitimi müfredatın ana odağını oluşturmuştur (MEB, Talim ve Terbiye Kurulu Başkanlığı Basın Açıklaması, 2017, s.7). Programlarda öğrencilere aktarılması hedeflenen kök değerler "adalet, dostluk, dürüstlük, öz denetim, sabır, saygı, sevgi, sorumluluk, vatanseverlik, yardımseverlik” olarak on ana başlık altında toplanmıştır. Yenilenen programlarda değerler ve değerlerle ilişkili tutum ve davranışlar, bakanlığın basın toplantısı için hazırladığı dokümanda bir tablo halinde sunulmuştur:

\begin{tabular}{cc}
\hline Değerler & Değerlerle ilişkili tutum ve davranişlar \\
\hline Adalet & âdil olma, eşit davranma, paylaşma... \\
Dostluk & diğerkâmlık, güven duyma, anlayışlı olma, dayanışma, sadık olma, vefalı olma, \\
Dürüstlük & yardımlaşma... \\
& açık ve anlaşılır olma, doğru sözlü olma, güvenilir olma, sözünde durma...
\end{tabular}


öz denetim

Sabir

Sayg

Sevgi

Sorumluluk

Vatanseverlik

Yardımseverlik davranışlarını kontrol etme, davranışlarının sorumluluğunu üstlenme, öz güven sahibi olma, gerektiğinde özür dileme...

azimli olma, tahammül etme, beklemeyi bilme...

alçakgönüllü olma, başkalarına kendine davranılmasını istediği şekilde davranma, diğer insanların kişiliklerine değer verme, muhatabının konumunu, özelliklerini ve durumunu gözetme...

aile birliğine önem verme, fedakârlık yapma, güven duyma, merhametli olma, vefalı olma...

kendine, çevresine, vatanına, ailesine karşı sorumlu olma; sözünde durma, tutarlı ve güvenilir olma, davranışlarının sonuçlarını üstlenme..

çalışkan olma, dayanışma, kurallara ve kanunlara uyma, sadık olma, tarihsel ve doğal mirasa duyarlı olma, toplumu önemseme...

Bu değerler, öğrenme öğretme sürecinde hem kendi başlarına, hem ilişkili olduğu alt değerlerle ve hem de öteki kök değerlerle birlikte ele alınarak hayat bulacaktır (MEB, 2019: 4). Öğretim programlarında belirlenen hedeflere ulaşmada metinler önemli bir rol oynamaktadır. Türkçe Ders kitaplarında metinler, öğrencilere ana dili bilinci ve sevgisi kazandırılmasında önemli materyaller olarak görülmektedir (Kolaç, 2009). Güliver'in Gezileri 1726'da tamamlanmış ve yayımlandığından bugüne dünya edebiyatının en çok okunan romanları arasında yer almıştır. Jonathan Swift'in dört bölüm olarak yazdığı bu roman, kısaltılmış basımlarıyla dünya çocuk edebiyatının da en çok tanınan eserleri arasındadır. Eser, gemilerde doktorluk yapan Lemuel Gulliver adlı kahramanın hayali dört ülkeye gezilerini anlatır. Yazar, hayalinde tasarladığı bu dört ülke nezdinde, esasında yaşadığı toplumdaki insan ilişkilerini, âdetleri, ahlaki zaafları, siyasî çekişmeleri, çeşitli kurumların işleyişindeki aksaklıkları roman kurgusu içinde eleştirmiştir. İrlandalı bir yazar olan Swift, otuzlu yaşlarının başında Londra'ya yerleşmiş ve burada siyaset, din ve edebiyat alanındaki yazdığı polemikleriyle ünlenmiştir. Girdiği siyasal mücadelelerden yıpranmış olarak Duplin'e dönen (1714) yazar, kendisini İrlanda'nın sorunlarına adamış ve ülkesinde ulusal bir kahraman haline gelmiştir. Bu eserin çocuklar için daha çok "cüceler" ve "devler" ülkelerinde geçen ilk iki bölümündeki maceraları içeren baskıları yapılmaktadır. Çocuk okurlar, romanın birinci bölümü olan Lilliput’a Gezi’de Güliver’i ve ailesini tanıyor, geziye çıkmasının nedenlerini öğreniyor, geminin batmasıyla kahramanın yüzerek kurtulmasını ve Lilliput ülkesinde yakalanmasıyla başlayan maceraları heyecan ve zevkle okuyorlar. Bilişsel düzeyi yüksek yetişkin okur ise, bu cüceler ülkesinde -18. yüzyıldaki İngiltere ve İngilizler özelinde anlatılan ama her ülkede görülebilecek- parti kavgalarının, inanç eksenli tartışmaların, çıkar çekişmeleri ve entrikaların, toplum ve devlet hayatındaki aksaklıkların roman sınırları içinde hicvini bulmaktadır. Yazar, ilk iki bölümdeki sosyal eleştirilerini üçüncü ve dördüncü bölümlere göre daha kapalı ve dengeli bir biçimde yapmıştır. Olaya dayalı metin kurgusu içinde insanın insanla, insanın toplumla, toplumların toplumlarla ilişkileri ve çatışmaları roman türünün gerekleriyle ele alınmış; toplum ve devlet hayatındaki iyi ve kötü, doğru ve yanlış, güzel ve çirkin bir arada gösterilerek yanlışlık ve kötülüklerin hicvine ve çözümüne dair işaretler verilmiştir. Eser, insan ilişkilerindeki tezatlıklara vurgu yapan kurgusu ve iletileriyle değerler aktarımı açısından elverişli bir metindir. Davranış ikilemlerini içeren metinlerin tartıştırılması öğrencilere değer kazandırma adına yapılabilecek işlemlerin başında yer almaktadır. Değer kazandırma adına yapılabilecek en doğru yol da budur. "Ş̧пn yap, bunu yapma” yollu bir değer eğitimi gerçekleştirilememektedir (Cemiloğlu, 2020: 17). Güliver’in Gezileri, bir bölümü cüceler, bir bölümü de devler ülkesinde geçen ve davranış ikilemleri yoluyla insan ilişkilerindeki tezatlıkları sembolik varlıklarla yansıtan bir eserdir. Bu araştırmada 
Güliver'in Gezileri adlı eserin Türkçe Dersi Öğretim Programı'nda yer alan on kök değer ve bu değerlerle ilişkili tutum ve davranışlar açısından incelenmesi amaçlanmıştır.

\section{Yöntem}

\section{Araştırmanın deseni}

Araştırmanın verilerinin elde edilmesinde nitel araştırma yöntemlerinden doküman inceleme yöntemi kullanılmıştır. Doküman incelemesi, yazılı materyallerin araştırılması hedeflenen durum, olay ve olgular hakkında analiz edilmesini içeren bir desendir (Ylldırım ve Şimşek, 2006). Bu araştırmada Jonathan Swift'in dört bölüm olarak yazdığı Güliver'in Gezileri adlı eseri Türkçe Dersi Öğretim Programı'nda yer alan on kök değer ve bu değerlerle ilişkili tutum ve davranışlar açısından incelenmiştir.

\section{Araştırmada incelenen eser}

Araştırmada Jonathan Swift'in dört bölüm olarak yazdı̆̆ı Güliver'in Gezileri adlı eseri Türkçe Dersi Öğretim Programı'nda yer alan on kök değer açısından incelenmiştir. Araştırmada bu eserin seçilme nedeni bu eserin hem tür hem de içerik bakımından her yaştan okurun ilgisini çekmesidir. Güliver ilk gezisinde cücelerin arasında bir dev gibi, ikinci gezisinde ise devlerin arasında bir cüce gibi kalmıştır. Yazar oluşturduğu bu tezatlı durumla bilginin göreceliğine; sevgi, saygı, adalet, yardımseverlik gibi değerlerin önemine göndermeler yapmış, sanat sınırları içinde kalarak okuruna açık ve kapalı iletilerde bulunmuştur. Güliver üçüncü gezisini müzik ve matematikle ilgilenen Laputa adlı bilim ülkesine yapar. Bu ülkede yaşayanlar yalnızca müzik ve matematikle ilgilenmektedirler. Soyut düşüncelere yoğunlaştıklarından günlük hayatın somut ve pratik bilgilerinden yoksundurlar. Günlük yaşantının gerektirdiği işleri ve düşünceleri uşaklarının yardımıyla yaparlar. Eserin bu bölümünde özellikle tek yanlı bilgi, beceri ve davranış geliştirmenin sakıncalarına yönelik iletiler yer almaktadır. Güliver son gezisini yöneticisi atlar olan bir ülkeye yapar. Atlar ülkesindeki yaşamı gözleyen Güliver onlara hayranlık duyar ve orada yaşamak ister. Güliver'den ülkesindeki çıkar kavgalarını ve dönem Avrupa'sındaki savaşları dinleyen asil atlar bu durumu anlamakta güçlük çekerler. Eserin bu bölümü, öğretim programlarımızda yer alan ve on kök değerle ifade edilen (adalet, vatanseverlik, dostluk, öz denetim, sorumluluk, saygı, sevgi, dürüstlük, yardımseverlik ve sabır) değerleri ve bu değerlerle ilişkili tutum ve davranışları benimsemiş bireylerin oluşturabileceği bir ülkeyi anlatmaktadır.

\section{Araştırmanın veri toplama aracı}

Güliver'in Gezileri adlı eser okunarak cümlelerdeki on kök değerin yer alma durumu ve bu değerlerle ilişkili öğrencilere kazandırılacak tutum ve davranışlar yönüyle incelenip belirlenmiştir. Belirlenen ifadeler sayfa sayıları verilerek ilgili olduğu başlığın altında yorumlanmıştır.

\section{Araștırmanın veri analizi}

Araştırmanın verileri betimsel analizle incelenmiştir. Betimsel analiz; bir çerçeve oluşturma, tematik çerçeveye göre verilerin işlenmesi, bulguların tanımlanması, bulguların yorumlanması olmak üzere dört aşamadan oluşur (Altunışık, Çoşkun, Bayraktaroğlu ve Yıldırım, 2010: 322). Güliver’in Gezileri eserinden elde edilen veriler on kök değer ve bu değerlerle ilişkili tutum ve davranışlar üzerine yorumlanmış ve değerler eğitimine olan katkısı incelenmiştir. 


\section{Geçerlik ve güvenirlik}

Araştırmada elde edilen veriler, farklı uzmanlar tarafından analiz edilerek araştırmacı çeşitlemesi yapılmıştır. Araştırmanın bulgular bölümünde eserden aynen alıntılar yapılarak verilerin inandırıcılığı arttırılmıştır. Araştırmanın bulguları genellenerek dış geçerlik sağlanmıştır. Araştırmanın iç güvenirliğini sağlamak amacıyla başka araştırmacıların verileri incelemesi ve doğrulaması sağlanmıştır (Merriam, 2013).

\section{Bulgular ve yorum}

Araştırmanın bu bölümünde "Güliver’in Gezileri” adlı eserin değerler bakımından çözümlemesi ve yorumları yapılmış, sayfa numaraları verilerek ilgili alıntılar gösterilmiştir. İletiler incelendiğinde Türkçe Dersi Öğretim Programı’nda yer alan on kök değere ilişkin bulgulara rastlanmıştır.

\section{Adalet}

"Adalet” sözcüğü, Türkçe Sözlük’te "yasalarla sahip olunan haklarm herkes tarafindan kullanılmasının sağlanması, türe; hak ve hukuka uygunluk, hakkı gözetme; herkese kendine uygun düşeni, kendi hakkı olanı verme, doğruluk" (https://sozluk.gov.tr) olarak tanımlanmıştır. Cemiloğlu'na göre öğrencilere kazandırılacak ilk değer "adalet” olmalıdır. Psikologlar; iyiler, doğrular ve güzeller içerisindeki en üst değerin adalet olduğunu savunurlar (2020: 18).

Adalet, toplum yaşamının merkezinde duran bir ahlâkî standarttır, genel olarak toplum kuramında ve toplumsal eylemlerde önde gelen bir rol oynadı̆̆ı düşünülür (Marshall, 1999: 735).

Aşağıda, eserde adalet değerinin bir ileti olarak yer aldığını gösteren bazı örnekler sunulmaktadır:

"Belki duymuşsunuzdur, yetmiş aydan beri imparatorluğumuzda giydikleri ayakkabıların ökçelerine göre isim almış iki siyasi parti mücadele halinde. Yüksek Ökçeler'in eski anayasaya Alçak Ökçeler'den daha fazla uydukları göze çarpıyor. Ama gene de majeste bütün resmi dairelerde yalnız Alçak Ökçeler'e iş verilmesini emir buyurmuş. Zaten kendisinin giydiği ayakkabıların ökçeleri de sarayda herkesinkinden alçaktır. Bu iki parti arasındaki düşmanlık o kadar arttı ki beraber ne yiyorlar ne de içiyorlar." (Swift, 2007: 32)

Alıntıda, giydikleri ayakkabıların ökçelerine göre isim almış iki partinin çekişmesi ve kralın bu partiler arasında taraf tutması gibi mizahî bir yaklaşımla, iktidar sahiplerinin yasalara ve anayasaya bağlı kalmaları ve halka âdil davranmaları gerektiği iletisi verilmektedir. Kralın desteklediği parti mensuplarına ayrımcılık yapması ve iki parti arasındaki düşmanlık adalet duygusunu zedelemiş, ülke içindeki birlik ve huzuru bozmuştur.

\section{"Siyaset ve adaletten bahis açarak onu bu fikirden vazgeçirmeye çalıstım. Hür ve cesur insanların esir olmalarını istemediğimi bildirdim. Meclis de çoğunlukla benim düşüncemi kabul etti." (Swift, 2007: 32)}

Lilliput imparatoru, komşu ada ülkesi Blefuscu ile kavgalıdır ve bu ülke halkını da yönetimine katıp genel vali olarak yönetmek istemektedir. İrlandalı yazar Swift'in dönemin İngiltere Krallığı'nın sömürgeci genişleme politikasına gönderme yaptığı açıktır. Bu alıntıda, adalet değerine vurgu yapılmış, ülkelerin işgalinin ve sömürgeleştirilmesinin doğru olmayacağı düşüncesi savunulmuştur. 
"Hükümet aleyhine işlenen bütün suçların cezası çok ağırdır ama şayet sanığın suçu ispat edilemezse onu yakalattıran kimse ölüm cezasına çarptırılır ve bütün malı masum adama verilir. Fitnecinin hiç malı yoksa onun hesabına hükümet bu kanunu yerine getirir.” (Swift, 2007: 37

Iftiranın yanlışlığı ve hükümetlerin hukuka bağlı kalarak haklının ve adaletin yanında yer alması gerektiği anlatılmaktadır.

\section{Dostluk}

Dostluk, "bir insanla uzun süreli ilişki sonucunda o insana yönelik derin, kalıcı bir sevgi, duygusal bağlanma, özen ve ilişkiyi koruma arzusuyla tanımlanan sevgi” olarak tanımlanabilir (Budak, 2000: 225). Eserde dostluk değerine yönelik olduğu tespit edilen iletilerden bazıları şunlardır:

"Birbirinize samimi arkadaşlık hisleriyle bağlandığınız için bütün dünyanın ve yüksek mahkemenin kendini Dağ Adamı'yla suç ortağı sayacağını bile bile verilen emri yerine getirmek için fikirlerini açıkça anlattığını söyledi.” (Swift, 2007: 43)

Dostluk ve fedakârlık değerlerine ilişkin iletiler verilmektedir.

"Saraydaki kadınlardan bir kısmı oyunlarımı daha önce seyretmişler; güzelliğim, kibar tavırlarım ve zekâm hakkında inanılmaz şeyler anlatmışlardı.” (Swift, 2007: 68)

İnsanların bireysel yeteneklerinin toplumda bir karşılığının olacağına ve insan ilişkilerini olumlu yönde etkileyeceğine yönelik ileti içermektedir.

“Kral benimle konuşmaktan çok hoşlanıyordu.” (Swift, 2007: 73)

Bilgi ve görgü sahibi insanların toplumun her katında değer göreceği iletisi verilmektedir.

\section{Dürüstlük}

“Dürüstlük” sözcüğü, Türkçe Sözlük’te “doğru ve dürüst olma durumu, doğru olana yakışır davranış, doğruluk, adalet” (https://sozluk.gov.tr) olarak tanımlanmıştır. Bu değerle ilgili eserde geçen iletilerden bazıları şunlardır:

"Hile hırsızlıktan daha büyük suçtur. Çünkü bir adam mallarını hırsızlıktan koruyabilir. Hâlbuki kötü niyetle savaşmak daha zordur.” (Swift, 2007: 38)

$\mathrm{Bu}$ alıntıda hile, hırsızlık ve kötü niyet gibi olumsuzlukların verdiği tedirginlik duygusu dile getirilmiştir. Dürüstlük değerine sahip insanlarda bu türden kötü tutum ve davranışların olmayacağı iletisi de çıarılabilir.

"Bu adam ta baştan beri benim düşmanımdı; fakat hislerini saklamayı becerdiğinden yüzüme karşı iltifat ediyor, arkamdan kuyumu kaziyordu.” (Swift, 2007: 40)

İnsan ilişkilerindeki sahteliklere vurgu yapılmış; arkadaşlık ve dostluk gibi bağların dürüstlük değeri üzerinden kurulabileceği iletisi verilmiştir.

"Sizin bana yaptığınız iyiliklere karşılık ben de kafamın uçurulması tehlikesini göze alarak olup bitenleri günü gününe haber vermeye çalışacağım.” (Swift, 2007: 42)

İyiliklere karşı vefa ve minnet duygusu beslemek, dürüst insan olmanın erdemlerindendir. Dürüstlük iyilikten yana olmayı gerektirir. İyiliklere karşı nankör olmak, dürüst insan davranışı değildir. 


\section{Öz denetim}

“Öz denetim” sözcüğü, Türkçe Sözlük’te “daha önemli bir amaca ulaşabilmek için kişinin tepkilerini, davranışlarm veya başka amaca yönelme eğilimini denetleyip kısıtlaması, otokontrol" (https://sozluk.gov.tr) olarak tanımlanmıştır. Bu değerle ilgili eserde geçen iletilerden bazıları şunlardır:

"Yolculuk esnasında para biriktirdiğim gibi, boş saatlerimi de kitap okuyarak geçiriyordum. Eski, yeni bütün yazarların kitaplarını okumaya firsat bulmuştum. Karaya çıktığım zaman halkın yaşayışıla ilgileniyordum. Hafizam çok kuvvetli olduğu için kendi kendime birkaç dil de öğrenmiştim.” (Swift, 2007: 6)

Kişinin öz denetime sahip olarak edinebileceği maddî ve manevî kazanımlara ilişkin iletiler verilmektedir.

"Ben de onların dilini az zamanda epey öğrenmiştim. Bazen imparator gelip derslerimi dinler, hocaların iyi çalışıp çalışmadıklarını kontrol ederdi.” (Swift, 2007: 18)

Öz denetim kişinin sahip olması ve kontrolü altında tutması gereken bir özelliktir. Bu değeri edinmiş bireyler başkalarının kontrol ya da denetimine ihtiyaç duymadan görev ve yükümlülüklerini yerine getirirler.

"Şeffaf kısmında bir daire üzerine çizilmiş garip şekiller gördük. Dokunmak istedik fakat o şeffaf madde buna mani oluyordu. Tahminimize göre bu ya meçhul bir hayvan ya da taptığı tanrı... Çünkü söylediğine bakılırsa onun fikrini almadan hiçbir şey yapmazmış. Her hareketinin zamanını bu makine tayin ediyormuş." (Swift, 2007: 20)

Bu cümlelerde günün hangi anı olduğunu gösteren bir alet olarak saat betimlenmiş ve zamanın insan hayatındaki önemi vurgulanmıştır. İnsan ömründe telafisi mümkün olmayan zamanın çok değerli olduğu, planlı bir şekilde kullanılarak boş yere harcanmaması gerektiği ve bunun da öz denetimle mümkün olabileceği düşüncesine yönelik yönelik iletiler verilmektedir.

"Ailem ve karımın yanında iki ay kadar kaldım, zira içimdeki gezip görme arzusuna daha fazla karşı gelemezdim." (Swift, 2007: 5)

Kişilerin yaşamlarını olumlu ya da olumsuz yönde etkileyebilecek kritik kararlar almalarında öz denetimin önemine değinilmiştir.

\section{Sabir}

"Sabır” sözcügü, Türkçe Sözlük’te "acı, yoksulluk, haksızlk vb. üzücü durumlar karşısında ses çlkarmadan onlartn geçmesini bekleme erdemi, dayanç; olacak veya gelecek bir şeyi telaş göstermeden bekleme” (https://sozluk.gov.tr) olarak tanımlanmıştır. Bu değerle ilgili eserde geçen iletilerden bazıları şunlardır:

"İmparator, sabrım ve iyi niyetlerim sayesinde kendisinin ve tebaasının gözüne girmemi istiyordu." (Swift, 2007: 19)

Azim ve kararlılıkla her işin üstesinden gelinebileceği ama bu süreçte sabırlı olmanın önemli bir değer olduğu iletisi verilmektedir.

"İçimden hep son günlerimi burada sessiz sedasız geçireyim diye dua ediyordum. Zavallı dul karımla yetim çocuğumuz hesabına matem tutmaya başladım.” (Swift, 2007: 55) 
Gerçekleşmesi beklenen iyi ve güzel hedeflere ulaşmak için sabırlı olmanın da gerektiği fikri işlenmektedir.

\section{Saygı}

“Saygı” sözcüğü, Türkçe Sözlük’te “değeri, üstünlüğü, yaşhlı̆̆ı, yararhlı̆̆ı, kutsallığı dolayısıyla bir kimseye, bir şeye karşı dikkatli, özenli, ölçülü davranmaya sebep olan sevgi duygusu, hürmet, ihtiram; başkaların rahatsı etmekten çekinme duygusu" (https://sozluk.gov.tr) olarak tanımlanmıştır.

Saygı davranışı; Goffman'ın toplumsal etkileşimin nezaket kuralları içinde, pürüzsüz bir şekilde sürmesini sağlayan çeşitli sosyal davranışlar için kullandığı terimdir. İnsanlar gereksiz çatışmalardan kaçınmak, uygarca etkileşmek için bu tür davranışlarla birbirlerine karşı saygı gösterirler (Budak, 2000: 659).

Bu değerle ilgili eserde geçen iletilerden bazıları şunlardır:

"Doğrusu bu adamların matematik bilgilerine hiç diyecek yok. İmparatorları da gayet bilgili, akıllı bir insan." (Swift, 2007: 12)

Bilgiye ve akla duyulan saygı ifade edilmiştir.

"Tavırları çok kibardı, her haliyle imparatorluğa yakışacak cinsten bir adamdı. Yirmi sekiz yaşlarında görünüyordu, yedi yıldan beri de ülkenin idaresini üzerine almıştı.” (Swift, 2007: 16)

İyi özelliklere, lider olma vasıflarına ve deneyime duyulan saygıya yer verilmiştir.

"Bunlar ilk gördüğüm adam gibi kllıkları kıyafetleri düzgün insanlar değillerdi. Herhalde uşak, hizmetçi, iş̧̧i takımından insanlardı.” (Swift, 2007: 55)

Dönemin sınıflı toplum yapısı içinde insanların dış görünüşlerine bakarak sosyal statüleri hakkında fikir yürütülmüştür. İnsanlara dış görünüşlerine ve sosyoekonomik durumlarına göre davranılmamalı, insanlara saygıda kusur edilmemelidir.

"Kral, vatandaşlarının hepsinden daha akıllı ve bilgiliydi; hele matematik ve felsefe hakkında pek çok şey biliyordu.” (Swift, 2007: 70)

Bilgiye ve liderliğe duyulan saygı gösterilmektedir.

"Kraliçenin odasında saraya mensup kadın ve erkeklerle konuşurken yanımdan geçen cücenin benimle alay eder gibi tavırlar takınması, beni kendinden küçük görmesi kadar beni üzen, utandıran bir şey yoktu." (Swift, 2007: 73)

Kişinin kendisine bakmadan karşısındakini yargılamasının yanlışlı̆̆ anlatılmıştır. Yazar, bir cücenin kendisinden daha kısa bir kişiyle alay etmesi ironisi üzerinden kişinin kendini bilmesi, ön yargıların yanlışlığı, insanları dış görünüşlerine göre değerlendirilemeyeceği ve insan ilişkilerinde saygı gibi iletiler vermektedir.

\section{Sevgi}


“Sevgi” sözcüğü, Türkçe Sözlük’te “insanı bir şeye veya bir kimseye karşı yakın ilgi ve bağlılık göstermeye yönelten duygu” (https://sozluk.gov.tr) olarak tanımlanmıştır. Bu değerle ilgili eserde geçen iletilerden bazıları şunlardır:

"Karımdan ve çocuklarımdan gözyaşı içinde ayrıldım.” (Swift, 2007: 52)

Aile sevgisinin değeri ve aile bireylerinden ayrı kalmanın doğuracağı hüzün duygusu dile getirilmiştir.

"Her saniyede, bizim öldürmek istediğimiz hayvanlara yaptığımız gibi onun da beni yere atıp ayağıyla ezmesinden korkuyordum.” (Swift, 2007: 56)

Bu cümlede empati kurularak insanların hayvanlara yaptığı kötü muameleler eleştirilmiş ve hayvan sevgisi iletisi verilmiştir.

"Vahşi hayvanların karşısında korkulu tavırlar takınmanın, onu zorla insana hücum ettirdiğini birçok kimseden duymuş, yolculuklarım esnasında bu sözlerin doğru olduğunu da anlamıştım. Onun için kedinin karşısında sakin durmaya çalışıyordum.” (Swift, 2007: 59)

Gerçek dünyada kedi, insana oranla küçük ve zayıf bir varlıktır. Rollerin tersine döndüğü hayali bir ülkede kedilerden daha küçük boyuttaki bir insan bu kez av pozisyonuna düşecektir. Doğada hayvanlar dünyasında geçerli olan güçlünün zayıfı ezmesi kanunu akıllı bir varlık olan insan ilişkilerinde geçerli olmamalıdır. Kedi-insan imgesi üzerinden insanı güç ve otorite üzerine düşünmeye yönelten iletiler verilmiştir. İnsanlar her işin temeline sevgi değerini koymalıdırlar.

"İki saat kadar uyudum, rüyamda kendimi evimde, karım ve çocuklarımla beraber görmüştüm. Gözlerimi açıp da kocaman bir yatağın içinde yapayalnız olduğumu anlayınca kederim büsbütün artt1.” (Swift, 2007: 60)

Aile sevgisi ve aileden uzak kalmanın doğuracağı özlem duygusu anlatılmıştır.

"Eğer kü̧̈ük kızın gösterdiği şefkat ve özeni anmadan geçersem kendimi asla affetmem." (Swift, 2007: 63)

Çocuklar insan toplumunun saf ve temiz varlıklarıdır. Sevgi ve şefkatleri çıkarsız ve hesapsızdır. Çocuk masumiyetine sahip insanlardan oluşan bir toplumda sevgi ve şefkat hüküm sürecek, kavgalar ve savaşlar son bulacaktır. Yazar dönemin Avrupa'sında yaşadığı insan ilişkilerindeki olumsuzluklara yönelik iletiler vermektedir.

"Beni gözünden ayırmaya dayanamayan küçük dadım, odanın kapısında durmuş bizi dinliyordu." (Swift, 2007: 70)

Kişiye duyulan sevginin koruma duygusunu da beraberinde getirdiği anlatılmaktadır.

\section{Sorumluluk}

"Sorumluluk” sözcügü, Türkçe Sözlük’te "kişinin kendi davranışların veya kendi yetki alanına giren herhangi bir olayın sonuçların üstlenmesi, sorum, mesuliyet” (https://sozluk.gov.tr) olarak tanımlanmıştır. Bu değerle ilgili eserde geçen iletilerden bazıları şunlardır:

"Babamın Nottinghamshire'da biraz toprağı vardı. On dört yaşına geldiğim zaman, beni Cambridge'te bir liseye gönderdi. Mektebin masrafı çok azdı ama beş çocuklu fakir bir ailenin üçüncü oğlu olduğumdan, ancak üç yıl okuyabildim.” (Swift, 2007: 5) 
Ebeveynlerin çocuklarını yetiştirme ve hayata hazırlama sürecinde birçok sorumlulukları vardır. Her anne baba imkânları ölçüsünde bu sorumluluklarını en iyi şekilde yerine getirmelidir. Sorumluluk bilinci bireylere aile ve eğitim kurumları tarafından bir değer olarak kazandırılmalıdır.

“Majeste, bir süre önce ülkemize ayak basan Dă̆ Adamı'ndan aşağıdaki emirleri yerine getirmesini istemektedir." (Swift, 2007: 28)

Dă̆ Adamı'ndan ülkesi için yerine getirmesi gereken sorumluluklar sekiz madde halinde listelenmiştir. Her ülkenin vatandaşlarına karşı görev ve sorumlulukları olduğu gibi, vatandaşların hakları yanında ülkelerine karşı görev ve sorumlulukları vardır.

"Bu yollarda gezerken de sevgili vatandaşlarımıza ve onlara ait hayvanlara bir zarar getirmemelidir. Ayrıca herhangi bir kimseyi, kendi arzusu olmadan avcuna alması da menedilmiştir.” (Swift, 2007: 28)

İnsanların hem birbirlerine karşı hem de hayvanlara karşı sorumlulukları vardır. Kişilerin dokunulmazlık haklarına da dikkat çekilmektedir.

"Blefescu Adası'ndaki düşmanlarımıza karşı bizim müttefikimiz olacak ve ülkemizi istila için hazırlanmakta olan donanmayı ortadan kaldırmaya çalışacaktır.” (Swift, 2007: 28)

Bir vatandaş olarak insanların mensubu oldukları ülkeye ve millete karşı sorumlulukları vardır. İnsanlar gerektiğinde bu değerleri korumak için savaşmalı ve vatanı uğrunda ölmeyi de göze almalıdır. Bu iletide sorumluluk ve vatanseverlik birbirini gerektiren değerler olarak birlikte verilmiştir.

"Yemek ve uyku saatleri hariç (buna da gayet az bir zaman ayrılır) çocuklar hep bir işle meşgul olur fakat ondan sonra herkes kendi işini yapmaya mecburdur." (Swift, 2007: 38)

Bir işle meşgul olmanın ve sorumluluğun önemi anlatılmaktadır.

\section{Vatanseverlik}

“Vatanseverlik” sözcüğü, Türkçe Sözlük’te "yurtsever olma durumu, vatanseverlik; yurtsevere yakışır davranış, vatanperverlik” (https://sozluk.gov.tr) olarak tanımlanmıştır.

Bu değerle ilgili eserde geçen iletilerden bazıları şunlardır:

"Artık bayağı onların dilini konuşmaya başlamıştım. Söylediğim ilk sözler hep hürriyete, serbest yaşamaya dair şeylerdi.” (Swift, 2007: 18)

Ülkesinden uzakta ve gözetim altında yaşayan bir insanın hürriyete ve özgürlüğe olan özlemi dile getirilmiştir. Hürriyet ve özgürlüğünü vatanından ayrı düştüğü için kaybetmiştir.

"Her şeyden önce, "Lumos kemlin pesso des mar lon Emposo" yani imparatorla ve ülkenin insanlarıyla sulh içinde yaşayacağıma yemin etmeliydim.” (Swift, 2007: 19)

Güliver yabancı bir ülkede yaşamak zorunda kalınca o ülkenin kurallarına uyacağına dair vatandaşlık yemini etmek zorunda kalır. Vatandaşlık bilincine yönelik iletiler verilmiştir.

"Hürriyetimi kazanmak için o kadar çok dilekçe yazmış, o kadar çok yalvarmıştım ki sonunda imparator daha fazla dayanamayarak meseleyi ilkin kabinede sonra da mecliste görüştü." (Swift, 2007: 27) 
Yaşanılası bir vatan için insan hak ve hürriyetinin kutsal bir değer olduğu, bu değerler uğruna mücadele edilmesi gerektiği vurgulanıyor. Eserin yazıldığı dönem dikkate alındığında Meclis’i işleyen toplumlarda bu değerlere ulaşmanın daha kolay ve mümkün olduğu iletisi verilmektedir.

"Memleketimiz çok mükemmeldir. Fakat buna rağmen başımızda iki büyük bela var: birincisi memlekette isyan tehlikesi, ikincisi ise en kuvvetli düşmanımız tarafından istilaya uğramamız." (Swift, 2007: 27)

Vatan sevgisi ve ülke sorunlarına karşı duyarlı olmanın önemi anlatılmaktadır.

\section{Yardımseverlik}

"Yardımseverlik" sözcüğü, Türkçe Sözlük’te "Hayırsever olma durumu, iyilikseverlik, hayırperverlik" (https://sozluk.gov.tr) olarak tanımlanmıştır. Yardım; tipik olarak kişisel bir risk taşımayan ve ufak tefek ricaları yerine getirmeyi içeren sosyal bir davranıştır (Budak, 2000: 830).

Bu değerle ilgili eserde geçen iletilere örnekler:

"Bahsi geçen Dağ Adamı, boş zamanlarında işçilerimizin ağır taşları kaldırmalarına yardım edecektir.” (Swift, 2007: 29)

Insanlar firsat buldukça bilgileri ve yetenekleri dâhilinde başkalarına da yardım etmelidir. Sosyal bir varlık olan insan içinde yaşadığı toplumun bireylerinden kendisini soyutlayamaz. Toplumsal dayanışma ve yardımlaşma toplumun birliği ve refahı açısında da önemlidir.

“...ama hayatım pahasına, dışarıdan gelecek düşmanlarla onun uğruna çarpışmaktan çekinmeyeceğimi de anlatmasını rica ettim.” (Swift, 2007: 32)

Dünya barışı ve ülkeler arası ilişkiler açısından yardımseverliği anlatmaktadır.

"Bu adam henüz sarayda nüfuz sahibi değilken benim ona pek çok yardımım dokunmuştu” (Swift, 2007: 41)

Alıntı cümlede olduğu gibi, nüfuz sahibi olmayan bir insana yardım etmek, karşllı beklemeksizin yapılan güzel bir davranış örneğidir. İnsanların toplumsal davranışları sevgi ve saygı temelinde gerçekleşmeli, sosyal ve ekonomik statülere göre şekillenmemelidir. Sosyoekonomik durumu zayıf insanları aşağılamak ya da güçlü durumdakilere yaranmaya çalışmak kişilik sahibi bir insan davranışı değildir. Yazar, tek bir cümleyle yardımseverlik değerine ilişkin açı ve örtük iletiler sunmuştur.

\section{Sonuç}

Sosyal hayatın bir tür aynası olan edebiyat metinleri, ulusal ve evrensel değerlerin bireylere iletilmesinde ve gelecek kuşaklara aktarılmasında önemli bir rol oynamaktadır. Her yaştan okur, beğenerek okuduğu hikâye ve romanların kahramanlarıyla özdeşlik kurar. Okuduğu kahramanın duygularını, düşüncelerini, tutum ve davranışlarını anlamaya çalışır. Bunlardan bir kısmını farkına bile varmadan kendi duygu ve düşünce dünyasına katar, tutum ve davranışa dönüştürür. Öğretim programlarının hedeflerine ulaşmasında edebiyat metinlerinin sağlayabileceği bu tür katkılardan yararlanılmalıdır. Edebî eserler didaktik değil, estetik metinlerdir ve içerdikleri iletileri okurlarına telkin yoluyla sunarlar. Çocuklar bu tür metinleri kahramanlarıyla özdeşleşme duyguları içinde okur ve çıkardıkları iletileri içselleştirirler. Böylece daha kalııı izli öğrenme ve davranış değişikliği sağlanmış olur. Güliver'in Gezileri, yayımlandığından bugüne çocuk ve yetişkin okurların beğenisini kazanmış ve 
dünya klasikleri arasında yerini almış bir eserdir. Milli Eğitim Bakanlığı'nın değerler eğitiminde esas alınması gereken "on kök değer" ve bu değerlerle ilişkili tutum ve davranışlar açısından incelendiğinde, eserin içerdiği tema ve iletiler açısından bu amaca katkı sağlar nitelikte olduğu görülmektedir.

Elbir ve Bağcı (2013) tarafından değerler eğitimi üzerine yapılan tezler incelenmiş, Türkiye'de değerler eğitiminin yeteri kadar özümsenmediğini sonucuna ulaşılmıştır. "Eğitim sistemimizin temel amacı değerlerimiz ve yetkinliklerle bütünleşmiş bilgi, beceri ve davranışlara sahip bireyler yetiştirmektir.” Yenilenen öğretim programları "salt bilgi aktaran bir yapıdan çok bireysel farklılıkları dikkate alarak hazırlanmıştır. Öğrenme öğretme sürecinin planlanması ve uygulanması aşamasında öğretmenlerin işlenecek temalara uygun edebiyat metinlerini de birer öğretim materyali olarak kullanmaları kök değerlerin özümsenmesine, değerlerimiz ve yetkinliklerle bütünleşmiş bireyler yetiştirme hedefine katkı sağlayacaktır.

Baki (2019) araştırmasında Türkçe dersi 5. sınıf kitabında estetik, nezaket, mutluluk ve sevgi en fazla yer verilen değer iken barış, misafirperverlik ve hoşgörü en az yer verilen değerler olduğunu; 6 . sınıf ders kitabında en fazla sevgi değerine yer verildiğini; 7. sınıf düzeyinde ise estetik, samimiyet ve vatanseverliğin en çok aktarılan; sadelik, misafirperverlik, özgürlük ve barışın ise en az aktarılan değerler olduğunu; 8. sınıfta en fazla aktarılan değerlerin estetik, sevgi, çalışkanlık ve saygl; en az aktarılan değerlerin ise barış, sadelik, alçakgönüllülük olduğunu tespit etmiştir. Padem ve Aktan (2014) okuma metinlerinde en fazla sevgi, yardımseverlik, estetik; en az ise acıma, arkadaşlık, cesaret, doğruluk, fedakârlık değerlerine olduğunu belirtmiştir. Pilav ve Erdoğan (2016) ise metinlerde en çok sevgi ve ulusal değerlere yer verildiği, dürüstlük ve barış değerine ise yer verilmediğini tespit etmiştir. Çelikpazu ve Aktaş (2011), 6. sınıf ders kitaplarında en fazla sevgi değerinin yer aldığını, Aral (2008) ve Akyol (2010) araştırmalarında temizlik ve hoşgörü değerinin 6. sınıf ders kitabında en az yer verilen değer olduğunu tespit etmişlerdir. Çelikpazu ve Aktaş (2011) ile Pilav ve Erdoğan (2016) araştırmalarında 7. sinıfta en fazla aktarılan değerin sevgi olduğunu; Çapoğlu ve Okur (2015)'un 8. sınıf düzeyinde en fazla insan ve doğa sevgisi değerinin yer aldığını tespit etmiştir. Yapılan araştırmalar ders kitaplarının genel olarak sevgi değerinin kullanıldı̆̆ını göstermektedir. Ders kitaplardaki metinlerin değerleri eşit bir şekilde ve programda yer alan on kök değere göre aktarılması, öğrencilerin bu becerileri kazanması açısından önemlidir. Yapılan araştırmada Güliver'in Gezileri adlı eserde on kök değerin verildiği görülmektedir.

Birçok araştırmada Türkçe ders kitaplarında değerlerin öğrencilere yeterli düzeyde aktarılamadığı tespit edilmiştir (Şen, 2008; Parlakyıldız, 2009; Doğan ve Gülüşen, 2011; Çelikpazu ve Aktaş, 2011; Demir, 2012; Furat ve Mocan, 2014; Pilav, Demir ve Demir, 2015). Değerler eğitimi öğreticilikten ve zorlamadan uzak olmalıdır. Bir bölümü cüceler, bir bölümü de devler ülkesinde geçen ve davranış ikilemleri yoluyla insan ilişkilerindeki tezatlıkları sembolik varlıklarla yansıtan Güliver'in Gezileri, değerler eğitimi açısından elverişli bir eserdir. Öğretim programlarında yer alan değerleri çocuklara aktarmak, bu değerlerle ilişkili tutum ve davranışlar oluşturmak, okuma zevk ve alışkanlığı kazandırmak, dil bilinci uyandırmak gibi hedeflere ulaşmada çocukların yaş grubuna uygun her türden nitelikli edebiyat eserlerinin katkılarından yararlanılmalıdır.

Adil olma değeri birçok çalışmada değerler aktarımında önemli bir değer olduğunu vurgulanmıştır (Wood ve Roach, 1999; Dilmaç, 2007; Demir, 2008; Engin, 2014; Kapkın, 2018). Araştırmada incelenen eserde, anayasanın üstünlüğüne vurgu yapılarak siyasi partilere ve krala eleştiri yapılmış, adaletin toplum hayatındaki önemine değinilmiştir. Adalet, özgürlük ve demokrasi eserde en çok 
vurgu yapılan iletilerdendir. İftiranın yanlışlı̆̆ ve yol açacağı zararlar gösterilmekte, yöneticilerin hukuk sistemine bağlı kalarak haklının ve adaletin yanında olması gerektiği fikri işlenmektedir. Eserde dostluğun önemi ve fedakârlık anlatılmaktadır. Kişideki iyi özelliklerin insanları birbirine yaklaştırdığı ve bununla birlikte dostluk kurabileceği ifade edilmiştir.

Metinlerde doğruluk dürüstlük değerinin kullanılmasına ilişkin birçok araştırma yapılmıştır (Katılmış, 2010; Yalız, 2011; Izgar, 2013; Neslitürk, Özkal ve Dal, 2015; Erikli, 2016). İncelenen bu eser, hile, hırsızlık gibi doğru olmayan davranışları ayırarak okurunu dürüstlüğe ve iyiliğe yöneltme amacı taşımaktadır. Gerektiğinde dürüst davranış gösterme ve tercihini dürüstlükten yana kullanabilme yetisinin önemi yansıtılmıştır. Kişinin öz denetime sahip olarak edindiği maddi ve manevi kazanımlar anlatılmaktadır. Kendi kendini denetleme ve buna bağlı olarak karar vermenin önemi üzerinde durulmuştur. Sabırlı davranışların sonuçları ile ilgili fikirler edinme üzerinde durulmuştur. Sabırlı olmanın önemi anlatılmıştır. Bilgiye ve akla duyulan saygı ifade edilmiştir. Eserde cimrilik ve önyargıyla ilgili bölümler de yer almaktadır. Bilgiye ve liderliğe duyulan saygı gösterilmektedir. Aile özlemi ve aileden ayrı kalmanın hüznü anlatılmıştır. Hayvanları korumanın ve onları sevmenin öneminden bahsedilmiştir. Ebeveynlerin sorumlulukları anlatılmaktadır. Ayrıca eğitime verilen öneme ve yaşam koşullarına da yer verilmiştir. Mensup olduğu ülkeye ve millete karşı sorumluluklarının farkına varma iletisi vardır. Dilin, hürriyetin ve vatanın önemi vurgulanmaktadır. Ülkede barış içinde yaşamanın ve kanunlara saygılı olmanın öneminden bahsedilmektedir.

\section{Kaynakça}

Acun İ., Yücel, C., Önder, A. ve Tarman, Ö. (2013). Değerler: Kim ne kadar değer veriyor?. Uşak Üniversitesi Sosyal Bilimler Dergisi, 6(1).

Altunışık, R., Çoşkun, R., Bayraktaroğlu, S. ve Yıldırım, E. (2010). Sosyal bilimlerde araştırma yöntemleri (6.Baskı). Sakarya: Sakarya Kitabevi.

Aral, D. (2008). Millî Eğitim Bakanlı̆̆’nın hazırladiğı 6. Sinıf Türkçe ders kitabında yer alan değerler üzerine bir araştırma (Yayımlanmamış yüksek lisans tezi). Abant İzzet Baysal Üniversitesi, Eğitim Bilimleri Enstitüsü, Bolu.

Baki, Y. (2019). Ortaokul Türkçe ders kitaplarındaki metinlerin değer aktarımı açısından incelenmesi. Değerler Ĕ̆itimi Dergisi, 17, (37), 109-146. DOI: 10.34234/ded.460042

Budak, S. (2000). Psikoloji sözlüğü. Ankara: Bilim ve Sanat.

Cemiloğlu, M. (2020), The teaching of values in Turkish language and literature course. International Journal of Humanities and Research, 4(3), p. 17-23.

Çelikpazu, E. E. ve Aktaş, E. (2011). MEB 6, 7 ve 8. Sınıf Türkçe ders kitaplarında yer alan metinlerin değer iletimi açısından incelenmesi. Turkish Studies, 6(2), 413-424.

Çengelci, T., Hancı, B. ve Karaduman, H. (2013). Okul ortamında değerler eğitimi konusunda öğretmen ve öğrenci görüşleri. Değerler Eğitimi Dergisi, 11(25), 33-56.

Demir, M. R. (2008). İstasyonlarda öğrenme modelinin hayat bilgisi dersindeki üst düzey beceri erişisine etkisi. Hacettepe Üniversitesi Sosyal Bilimler Enstitüsü İlköğretim Bölümü, Ankara.

Demir, T. (2012). İlköğretim sekizinci sınıf Türkçe ders kitaplarındaki hikâye metinlerinde yer alan değer unsurlarının eşdizimsel örüntülemeler açısından görünümleri. Turkish Studies, 7(2), 1063-1078

Diker Coşkun, Y. (2017). Öğretim programları arka plan raporu. Eğitim İzleme Raporu 2016-2017, egitimreformugirisimi. org.

Dilmaç, B. (2007). Bir grup fen lisesi öğrencisine değerler eğitiminin insani değerler ölçeği ile sınanması (Yayımlanmamış Doktora Tezi). Selçuk Üniversitesi Sosyal Bilimler Enstitüsü Eğitim Bilimleri Anabilim Dalı, Konya. 
Doğan, Ö. (2004). Etik ahlâk felsefesi. İstanbul: İnkllâp.

Doğan, B. ve Gülüşen, A. (2011). Türkçe ders kitaplarındaki (6-8) metinlerin değerler bakımından ïncelenmesi. Kilis 7 Aralk Üniversitesi Sosyal Bilimler Dergisi, 1(2), 75-102.

Elbir, B. ve Bağcı, C. (2013). Değerler eğitimi üzerine yapılmış lisansüstü düzeyindeki çalışmaların değerlendirilmesi. Turkish Studies. 8(1), s.1321-1333.

Engin, G. (2014). Türkçe ve beden eğitimi öğretim programları ile bütünleştirilmiş değerler eğitimi programının etkililiği (Yayımlanmış Doktora Tezi). Çanakkale Onsekiz Mart Üniversitesi Eğitim Bilimleri Enstitüsü Eğitim Bilimleri Anabilim Dalı.

Erikli, S. (2016). Okul öncesi çocuklar için bir değerler eğitimi programının geliştirilmesi ve uygulanması (Yayımlanmamış Yüksek Lisans Tezi). Orta Doğu Teknik Üniversitesi Sosyal Bilimler Enstitüsü Okul Öncesi Eğitimi Anabilim Dalı, Ankara.

Fırat, H. ve Mocan, A. (2014). Türkçe ders kitaplarındaki hikâyelerde yer alan değerler. Türkiye Sosyal Araştırmalar Dergisi, 18(3), 25-49.

Güngör, E. (1998). Değerler psikolojisi üzerinde araşttrmalar (2. Basım). İstanbul: Ötüken.

Hökelekli, H. (2013). Değerler psikolojisi ve eğitimi. İstanbul: Timaş.

Izgar, G. (2013). İlköğretim okulu 8. sinı öğrencilerine uygulanan değerler eğitimi programının demokratik tutum ve davranışlarına etkisi. Necmettin Erbakan Üniversitesi Eğitim Bilimleri Enstitüsü Eğitim Bilimleri Anabilim Dalı, Konya.

Kapkın, B. (2018). Etkinlik temelli değerler eğitimi programının 5-6 yaş çocukların sosyal becerilerine etkisinin incelenmesi (Yayımlanmamış Yüksek Lisans Tezi). İnönü Üniversitesi Sağllk Bilimleri Enstitüsü Çocuk Gelişimi Anabilim Dalı, Malatya.

Karaca, S. S. (2019). Çizgi filmlerde değerler eğitimi, değerler eğitimi açısından rafadan tayfa çizgi filminin incelenmesi (Yayımlanmamış Yüksek Lisans Tezi). İzmir Kâtip Çelebi Üniversitesi Sosyal Bilimler Enstitüsü Felsefe ve Din Bilimleri Anabilim Dalı

Katılmış, A. (2010). Sosyal bilgiler dersindeki bazı değerlerin kazandırılmasına yönelik bir karakter eğitimi programının gelisstirilmesi (Yayımlanmamış Doktora Tezi). Marmara Üniversitesi Eğitim Bilimleri Enstitüsü İlköğretim Bölümü Sosyal Bilgiler Öğretmenliği Anabilim Dalı.

Koç, S. (2016). Ortaokul öğretmenlerinin değerler eğitimi konusundaki görüşleri. Kırıkkale Üniversitesi Sosyal Bilimler Dergisi, 6(1), 377-396.

Kuçuradi, İ. (1971). İnsan ve değerleri (değer problemi). İstanbul: Yankı.

Kuşdil, M.E. ve Kağıtçıbaşı, Ç. (2000). Türk Öğretmenlerin Değer Yönelimleri ve Schwartz Değer Kuramı. Türk Psikoloji Dergisi, 15(45), 59-76.

Marshall, G. (1999). Sosyoloji sözlüğü. (çev. O. Akınhay, D. Kömürcü), Ankara: Bilim ve Sanat Yayınları.

MEB (2017). Müfredatta yenileme ve değişiklik çalışmalarımız üzerine. TTKB Basın Açılaması, 18 Temmuz 2017. Erișim https://ttkb.meb.gov.tr/meb_iys_dosyalar/2017_07/18160003_basin_aciklamasiprogram.pdf. Erişim tarihi: 17.05.2020

MEB. (2019). Türkçe dersi öğretim programı (İlkokul ve Ortaokul 1, 2, 3, 4, 5, 6, 7 ve 8. Sinıflar). Ankara. http://mufredat.meb.gov.tr/Dosyalar/20195716392253-02T\%C3\%BCrk\%C3\%A7e\%20\%C3\%96\%C4\%9Fretim\%20Program\%C4\%B1\%202019.pdf. Erişim Tarihi: 08.05.2020

Merriam, S. B. (2013). Nitel araştırma desen ve uygulama için bir rehber (Çev. Ed. Selahattin Turan). Ankara: Nobel Akademik.

Neslitürk, S., Özkal, N. ve Dal, S. (2015). 5-6 Yaş çocuklarının değer kazanım süreçlerine anne değerler eğitimi programının etkisi. Mersin Üniversitesi Eğitim Fakültesi Dergisi, 11(3), 883-899. DOI: 10.1786o/efd.54144 
Padem, S. ve Aktan, O. (2014). İlköğretim 5. Sinıf Türkçe ders kitabında yer alan değerlerin incelenmesi. Düzce Üniversitesi Sosyal Bilimler Enstitüsü Dergisi, 4(2), 5-24.

Parlakyıldız, H. (2009). İlkokul ikinci devrede Türkçe ders kitaplarındaki moral değerlere kısa bir bakış (1948-1968 yılları arası). Uludağ Üniversitesi Eğitim Fakültesi Dergisi, 22(1), 245-262.

Pilav, S., Demir, H. A. ve Demir, H. (2015). İlköğretim 7. Sınıf Türkçe ders kitaplarındaki okuma metinlerinin değer iletimi açısından incelenmesi. Milli Ĕ̆itim Dergisi, 45(206), 16-29.

Pilav, S. ve Erdoğan, Ş. (2016). Ortaokul Türkçe ders kitaplarındaki bilgilendirici metinlerin değer iletimi açısından incelenmesi. Milli Ĕ̆itim Dergisi, 45(210), 351-371.

Sunar, S. (2018). Kalite artırmaya yönelik politikalar. Ed. Emin Karip, Eğitim değerlendirme raporu içerisinde. Ankara: TED

Swift, J. (2007). Güliver’in gezileri (2. Baskı). Ankara: Star Medya.

Şen, Ü. (2008). Altıncı sınıf Türkçe ders kitaplarındaki metinlerin ilettiği değerler açısından incelenmesi. Uluslararası Sosyal Araştırmalar Dergisi, 1(5).

Tarhan N. (2011). Güzel insan modeli. İstanbul: Timaş.

TDK. (2020). Güncel Türkçe sözlük. sozluk.gov.tr. Erişim Tarihi: 15.04.2020

Wood, R. W. ve Roach, L. (1999). Administrators' perceptions of character education. Education, 12O, $213 \square 238$.

Yarar Kaptan, S. (2015). İlkokul 4. sinıf sosyal bilgiler dersinde hoşgörü değerinin karma yaklaşıma dayal bilgisayar destekli etkinliklerle öğretimi (Yayımlanmamış Doktora Tezi). Gazi Üniversitesi Eğitim Bilimleri Enstitüsü İlköğretim Anabilim Dalı, Ankara.

Yıldırım, A. ve Şimşek, H. (2006). Sosyal bilimlerde nitel araştırma yöntemleri (2. Baskı). Ankara: Seçkin. 